\title{
Prostitution and Public Policy. The Nordic Model Versus the Pimping of Prostitution
}

Christopher A. Bagley

Liverpool John Moores University, chrisbagley2@gmail.com

Follow this and additional works at: https://digitalcommons.uri.edu/dignity

Part of the Law Commons, and the Social and Behavioral Sciences Commons

\section{Recommended Citation}

Bagley, Christopher A. (2018) "Prostitution and Public Policy. The Nordic Model Versus the Pimping of Prostitution," Dignity: A Journal of Analysis of Exploitation and Violence: Vol. 3: Iss. 1, Article 3. https://doi.org/10.23860/dignity.2018.03.01.03

This Book Review Essay is brought to you for free and open access by DigitalCommons@URI. It has been accepted for inclusion in Dignity: A Journal of Analysis of Exploitation and Violence by an authorized editor of DigitalCommons@URI.For more information, please contact digitalcommons-group@uri.edu. 


\title{
Prostitution and Public Policy. The Nordic Model Versus the Pimping of Prostitution
}

\author{
Abstract \\ In this review of recent books on public policy and prostitution, Julie Bindel's The Pimping of Prostitution \\ is sympathetically reviewed. Her thesis, that the libertarian movement seeking to remove prostitution \\ from legal and public policy spheres has done grave harm to the lives of boys, girls and women, is \\ elaborated by quotations from her chapters. This book is an important resource for those who campaign \\ for the rights of women and children to be free of commercial sexual exploitation. The reviewer offers a \\ critical realist perspective on Bindel's work, in advocating that future scholars should use her extensive \\ research for a theoretical elaboration of why the libertarian movement has, in some spheres been \\ successful.

\section{Keywords} \\ prostitution, public policy, feminism, child sexual abuse, adolescents, Nordic Model, women's accounts, \\ pimping, work, criminology, radical feminist

\section{Creative Commons License} \\ cc) (i) $€$ \\ This work is licensed under a Creative Commons Attribution-Noncommercial-No Derivative Works 4.0 \\ License.

\section{Acknowledgements} \\ Dignity thanks the following students for their time and expertise in editing this book review essay: Lily \\ Lachapelle, major in psychology and gender and women's studies with a minor in Arabic; and Doriana \\ Magliocchi, major in psychology with a minor in gender and women's studies, University of Rhode Island.
}


DIGNITY

Volume 3, Issue 1, Article 3, 2018
A JOURNAL ON

SEXUAL EXPLOITATION

AND VIOLENCE

PROSTITUTION AND PUBLIC POLICY: THE NORDIC MODEL VERSUS THE PIMPING OF PROSTITUTION

\author{
A REVIEW OF
}

WHAT IS TO DONE ABOUT CRIME AND PUNISHMENT? TOWARDS $A$ "PUBLIC CRIMINOLOGY," ROGER MATTHEWS (EDITOR) (LONDON: PALGRAVE-MACMILLION, 2016, 324 PAGES)

AND

THE PIMPING OF PROSTITUTION: ABOLISHING THE SEX WORK MYTH BY JULIE BINDEL (LONDON: PALGRAVE-MACMILLION, 2017, 368

PAGES; AUSTRALIA: SPINIFEX PRESS, 2017)

Christopher Adam Bagley

Liverpool John Moores University, UK

\title{
KEYWORDS
}

prostitution, pimping, work, Nordic model, criminology, radical feminist, public policy, feminism, child sexual abuse, women's accounts

\begin{abstract}
In this review of recent books on public policy and prostitution, Julie Bindel's The Pimping of Prostitution is sympathetically reviewed. Her thesis that the libertarian movement seeking to remove prostitution from legal and public policy spheres has done grave harm to the lives of boys, girls, and women, is elaborated by quotations from her chapters. This book is an important resource for those who campaign for the rights of women and children to be free of commercial sexual exploitation. The reviewer offers a critical realist perspective on Bindel's work, in advocating that future scholars should use her extensive research for a theoretical elaboration of why the libertarian movement has, in some spheres been successful.
\end{abstract}

$\mathrm{I}$ N THIS REVIEW I compare two policy approaches to the problems of commercialized sexual exploitation of women, girls, and boys: the 'realist' approach of Roger Matthews and his colleagues; and the radical feminist approach of Julie Bindel.

Since I have reviewed the edited book by Roger Matthews, What is to be done about crime and punishment? Towards a "public criminology," for another journal (Bagley, 2018) I will not review it fully here: suffice it to say that this book by 11 specialists from North America and Europe could form an excellent basis for a 
graduate course in criminology. I will focus here on two chapters in Matthews' edited book: chapter 4 by John Pitts on "Critical realism and gang violence"; and chapter 11 by Helen Johnson and Roger Matthews on the Nordic model.

In their chapter "Addressing prostitution: The Nordic model and beyond," Johnson and Matthews offer a comprehensive and sympathetic review of "the Nordic model," referring in particular to research from Sweden, laying emphasis on strategies for exiting imposed prostitution, and on preventing recruitment and entry into prostitution, which is seen to harm many of the girls and women upon whom it is imposed. The law, in Sweden and elsewhere they argue, is a starting point in this process and is not a comprehensive solution if work for rescue and rehabilitation is underfunded or undeveloped.

Johnson and Mathews conclude:

As we learnt from anti-smoking campaigns an effective strategy needs to engage with the issue at a number of different levels. There is a requirement to develop formal legal responses alongside more informal strategies that connect with the hearts and minds of the general public. Introducing the Nordic model in countries like the UK would no doubt be a very positive step, but for the legislation to be effective a number of other changes in policy and practice need to take place (p. 304).

The chapter by John Pitts, "Critical realism and gang violence" is a critical realist approach to street gangs that emphasizes models for public policy which could apply equally well to prostituted 'sex work.' Since I am an enthusiastic supporter of the critical realist approach to issues in the lives of disadvantaged groups, including the sexual violence imposed on girls and women, following the pioneering work of Priscilla Alderson (2013 \& 2015), I recommend Pitts' chapter as an exemplar of research analysis. Sawyerr and Bagley (2017) have elaborated the principles of the critical realist approach in sociological research elsewhere, and have applied it in various settings concerning children and youth (Bagley, Sawyerr \& Abubaker, 2017).

Critical realism is a value-based approach to social research, in which the researcher has a elaborated value commitment which motivates the undertaking of the research, and the interpretation of the research findings (usually using qualitative case studies). Critical realism is ontologically grounded on the recognition of the "absent actors," the ignored, invisible people whose real lives and sufferings society ignores. Abused and disadvantaged children form the ground of much of critical realist work (Saywerr \& Bagley, 2017). Their lives, needs, and struggles are elaborated in critical realist accounts, which identify the power systems in social structures which deny their rights. A process of morphogenesis is advocated, in which the voices of the oppressed become dialectically engaged with power systems in seeking social change. It seems to me that the situation of sexually abused children and adult women (abused through the imposition of prostituted sexuality) ideally fits the critical realist model of emancipation from a kind of slavery.

One of the facets of critical realism is the concept of underlaboring, an idea developed from the work of philosopher Thomas Hobbes. The underlaborer is the honest artisan who seeks the factual truth and exposes the paucity of logical reasoning of those who wish to maintain power systems (e.g. the pimps and brothel managers who pretend that they are engaged in "sex work," rather than in a form 
of modern slavery). A notable example of the underlaborer is the work of Engels, who built the logical groundwork on which Marx built his theses. ${ }^{1}$

I hope that Julie Bindel, author of The Pimping of Prostitution: Abolishing the Sex Work Myth, will not be offended if I describe her as an underlaborer. She is a hardworking researcher whose tireless work lays the logical basis for other scholars in their confrontation with those who advocate that prostitution belongs in the arena of unregulated free enterprise, in which women and children can be bought and sold, and subjected to the sexual cruelties of the men who purchase a period of their lives. The experience is an episode of slavery during which the temporary owner can rape a child or woman without legal sanction. I will return to this idea of underlaboring later on when I compare Julie Bindel's book with the recently published Pimp State by another British scholar, Kat Banyard (2015).

Julie Bindel's book is a long and impeccably researched book (with more than 1,000 detailed footnotes and references, including details of her interviews with women and men in the prostitution industry in many countries). She acknowledges a number of academics (including Matthews, 2008) whose work, in her estimation, has not been tainted by the corrupting ideologies of extreme libertarianism, or neo-liberalism. Bindel is British, but has worked with scholars across the world, including the American researcher Melissa Farley (Farley et al. 2009). Another one of her collaborators is Roger Matthews. She writes "Matthews is one of the few male academics who takes the view that prostitution is harmful to women and both a cause and consequence of their oppression" (p. 240). Indeed, Bindel and Matthews have cooperated in research on women who manage to exit from prostitution (Matthews et al., 2014). This research on the voices and personal accounts of women who have endured years of physical and psychological harm from commercial sexual exploitation suggests that such abuse often begins in childhood and adolescence. This leads to the powerful argument: legal systems which back away from helping the victims because "sex work" (sic) is seen as a free choice, are doing boys, girls, and women who are, or have been victims of child sexual abuse, a grave wrong.

Bindel's position is one of "radical feminism," developing the ideas of Andrea Dworkin, and she is profoundly opposed to the views of the faux-feminists who claim that women's best interests are served by allowing them to "freely" submit to paid-for-sex.

The fight to abolish the sex trade is part of a wider 'violence against women' movement. The challenges abolitionists face include the same challenges that some feminists face in naming sexual assault, domestic violence towards women and girls, but with one complication - prostitution involves money (p. 334).

\footnotetext{
${ }^{1}$ Critical realism (CR), exhorting the scholar to establish a value base for their research has attracted scholars whose work is overtly value based. Thus Margaret Archer (2012), one of CR's leading exponents, is the chief advisor on women's affairs to Pope Francis, and director of the Pontifical Research Centre in Lausanne. Other leading exponents of the CR research model have been Muslim social scientists, Quakers, and Marxist Humanists. All of these groups of scholars focus on alienation, the separation of oppressed groups from the achievement of their "natural" rights.
} 
Where there is money, there is corruption, which Bindel pitilessly exposes.

This book has been years in the making. The first chapter, The Abolitionist Movement, charts the emergence of the pro-profit, pro-prostitution movement which has corrupted much of what it has touched - including academic research and legal regimes in some countries - and has also led to the growth of trafficking or entrapment of girls, boys and women into prostituted sex roles which has brought great profit to those who control the sex industry, and much pain and misery in those who are forced to serve it. Bindel charts the emergence of the laudable Swedish model in which men are forbidden to purchase sex, while women endure no criminal penalties. She cites growing evidence that this policy diminishes the number of prostituted girls and women and also protects those who are unable to leave being prostituted, from the grossest harms (Johnson \& Matthews, 2016).

The apparent success of the Swedish or Nordic model has earned the wrath of neo-liberal and faux-feminist groups, who claim (without evidence) that it does not help women. Kat Banyard, in her book Pimp State: Sex, Money, and Equality (2016), observes: "Only one question then needs to be asked of the pro-prostitution lobbyist: if the Nordic Model is so inefficient in curbing the expansion of the sex trade, why are they so vehemently in opposition to it?" (p. 238). There is an analogy here with the tobacco industry which has lobbied against "plain packaging" of cigarettes on the grounds that it would not deter buyers. If this is true, why do they oppose the policy so strongly? Banyard observes that:

Sex trafficking is an embarrassment to the pro-prostitution lobby in the same way that lung cancer is to the tobacco industry. Despite claims to the opposite, feminist abolitionists do not 'rely' on scaremongering about the numbers of trafficking victims, or exaggerate the extent of the abuse and violence they endure (p. 18).

Bindel ends this chapter by writing:

Abolitionists have a goal: to bring about an end to the global sex trade, and to inhabit a world where no woman, man or child is prostituted - a world where sex is not bought, sold or brokered ... Why does this sound so crazy to so many people? (p. 33).

In her second chapter Bindel examines the 'sex workers' rights lobby' in detail, examining why they "campaign to normalize and decriminalize the global oppression of women and girls" (p. 33). This campaign certainly did not emerge from the voiced concerns of prostituted women, girls, and boys themselves, even though some lobby groups claimed this. In Cambodia for example (a country noted for ease of access to underage girls and boys) a fake union of sex workers was set up, in which an NGO (non-governmental agency) claimed that women and girls were happy to remain being prostituted because of the income it gave them. Bindel who visited this NGO shows that the women were in fact forced to remain in sexual bondage because the NGO would not purchase (for about $\$ 200$ ) a residence permit that would enable the women to work in the garment industry. Moreover (as I have found from fieldwork in South Asia) some NGOs exist to draw in international funding purportedly to help commercially sexually exploited women to 'exit': but if they were successful in this, lucrative funding would end for middle-rank 
professionals and government employees. Thus the NGO has a vested interest in keeping women in prostitution. Other bizarre notions that abolitionists have advanced is that becoming an "empowered" prostitute helps a woman overcome the trauma of sexual abuse in childhood.

The Cambodian situation is salutary since this country is a magnet for western men who wish to sexually abuse children and adolescents. Bindel records a conversation with a physician specializing in HIV prevention, who had worked in Cambodia:

Most of the girls I met were very young. Most of them started prostitution when they were infants. They were sold by their own family ... People involved in the traffic were giving money to the family, to buy girls. I've seen ... an international hotel ... depending on the time of night you would see very young girls, only 11 or 12 , that were sold ... (p. 200).

From my own work in Asia, I became aware of an NGO which obtained overseas aid funding to "prevent" young girls being prostituted, but was procuring these girls for foreign clients. This NGO has now closed, but the prospect of considerable profits allows the "liberal" policy of unregulated prostitution to thrive in a variety of forms, and in a number of different countries. For some countries, prostitution is a valuable form of earning foreign currency: very little of this goes to the exploited prostitute class.

Bindel gives an account of a British academic who studied trafficked women for his doctorate and published his thesis at the University of Amsterdam Press (2009). Bindel writes that he "... challenges every common presumption that exists about the trafficking of women for the sex trade." Even trafficked women, according to this author, had made a positive choice to better themselves through migration" (p. 249). This 'scholar' included in his informants two 16-year-old girls "making free choices." In his book he records an informant who describes how he and his associates bought a teenage girl from her father, an Albanian peasant:

The farmer put his daughter in my van and we drove back to Elbasan ... on the way we all fucked her and then after a few weeks we sent her to Italy ... every week she send me money ... no complaining. She is a good girl who knows her place (p. 250).

This is an academic record of research published by the University of Amsterdam, research which had ethical approval from the British University of Sussex. Another Sussex researcher described how he used his "erotic subjectivity" to flirt with underage boys in the sex trade, to establish a "non-straight" rapport in eliciting their accounts (p. 253). Another UK researcher who interviewed young boys who were engaged in survival sex writes approvingly of their enterprising lifestyles: any harms which arise come from the stigma attached to being "gay boys," not from their lack of any other means to support themselves (p. 293). Choosing 'sex work,' according to another author in this school of anthropology, empowers disadvantaged children (p. 294).

Dr. John Davies, the Sussex University academic whose book gave vivid (and apparently approving) accounts of girls trafficked from Albania was a frequent world traveler, lobbying for the end to all controls on the prostitution industry. This did not prevent him from setting up foundations which claimed to be able to 
help women to exit prostitution, for which he received international funding from European sources more than $£ 5$ million which, apparently, he used as investment funding for trafficking and brothel keeping in Asia and Europe. With the aid of a large grant from the Norwegian government, he set up an NGO in Bangladesh. He became Chief Technical Advisor to the Ministry of Women and Children in Bangladesh advising on ways to prevent trafficking and on the "liberation" of prostituted girls and women. The activities of this man were eventually exposed when it was realized that he was making considerable profits from "women, drug and gambling related illegal activities" (p. 245).

In 2016 Davies received a 12-year jail term from a British court for fraud, deceit, and corruptly misusing charity funds. He had previously survived earlier trials on charges of rape of a minor, and on the trafficking of infants (Bindel, 2016).

I think Bindel is right to expose unsavory characters such as these, since Davies is by no means alone in producing charlatan, pseudo-scholarship, and inventing terminology which aims to make traffickers and profiteers from prostituted women, respectable.

In her third chapter, Sanitising the Sex Trade, Bindel focuses on the efforts of those who advocate the complete deregulation of paid-for sexual exploitation (e.g., the German model), to alter language and concepts surrounding prostituted sex. They have coined the term "sex worker" to include the brothel profiteers, the pimp managers, and the women themselves within this nomenclature. This pro-prostitution lobby ignores the accounts of the prostituted women, of trafficking, violence from pimps and clients, psychological and physical harms, and substance use as the only way of dulling the physical and mental pain of many bodily intrusions each day. Very few women have become wealthy from prostitution by becoming pimps themselves. For most women, they entered prostitution in a state of poverty and left in the same economic state. On the distortion of language as a public relations exercise, Bindel quotes the incisive comment of Janice Raymond (2014): "Instead of SLAVES, let Negroes be called ASSISTANT PLANTERS and we shall not then hear such violent outcries against the slave trade by pious divines, tender-hearted poetesses and short-sighted politicians" (p.68).

Bindel points out that the "sanitizers" ignore or distort evidence on the sufferings of prostituted women and children: "The story the sex trade survivors tell is, unsurprisingly, vastly different from what we hear from the academics, pimps and sex buyers." (p. 75). And accounts given by the buyers show that rather than being concerned about the manifest sufferings of the women whom they purchase to rape, some are turned on by a woman's suffering. Other men were unconcerned, or were excited when the person they were buying was a juvenile. Some men asked the woman they had bought to "act like a little girl or to pretend to be the man's daughter while he raped her.

Chapter 4 is concerned with The Realities and Consequences of Legislation. Bindel gives us overviews of the policies and legal changes concerning prostitution in Germany, New Zealand, The Netherlands, Turkey, and Britain. All of these libertarian regimes have many disadvantages for prostituted women, and seem to increase the risk of uncontrolled trafficking, and violence in women's lives. Some of those who write about women killed by the men who purchased them describe "murder by a man acting as a client" - not an actual male buyer, the "honest john" - another grotesque distortion of language. 
Bindel writes: "The reality is that when you decriminalize or legalize pimps and sex buyers there is always a massive expansion of the sex trade. Multi-storey brothels are only ever built under such legislation" (p.114). Furthermore:

Another failure of legislation and decriminalization as evidenced by the Netherlands, Germany and New Zealand is that once prostitution becomes viewed and framed as a regular job, the impetus to provide any exiting service disappears (p. 117).

This is an important finding, countering claims that deregulation will be followed by a lowering of rates of HIV and STIs. Even if deregulation allowed women more control of client interactions (which is moot) regarding insisting on condom use, the doubling of the number of prostituted women under deregulation is likely to lead to more STIs, not less, according to Bindel's interviews with medical specialists. Deregulation also allows "special markets" for underage girls (aged 12 to 15) to thrive in certain city areas. When the authorities back off from monitoring prostituted women and their clients, evil thrives. "The government in the Netherlands has clarified that it is legal for driving instructors to offer lessons in return for sex, as long as the students are over the age of 18” (p. 121). Using this logic, it would be legal for a casting director to require a young actor to submit to sex, in return for the promise of tutelage or casting for a role in a movie or play. Under deregulation, the market rules and profits are maximised by reducing costs. A prostituted woman in New Zealand told Bindel: "If we don't get the Nordic model here in time, we will be whoring for minimum wage and may as well have just worked at MacDonald's" (p. 124). This situation raises the question of why women don't just walk away from prostitution. The reason is that many have been psychologically subjugated into a role of learned helplessness, and many also need money to service drug use since drugs are the only way of 'spacing out' or dissociating themselves from the daily pain and humiliation of prostituted work.

In her fifth chapter Bindel considers The Invisible Man, who purchases rights of ownership to rape a child or woman. This right of ownership is a field of Bindel's original research, and she makes many incisive observations, such as:

Children abused into the sex trade have often experienced life-changing violence from punters. The men who buy them might find it particularly difficult to delude themselves into thinking that a girl or boy standing on a street corner looking for 'business' is making any kind of choice or that this is something s/he is happy to do. Of all the women I have spoken to who were prostituted as children, only one survivor told me that one time a punter, on realizing she was under the age of consent (16 in her country) gave her a reprieve (p. 141).

Bindel quotes the Sexual Freedom Coalition guidelines on the use of learning disabled children and adults as objects in prostitution: "Where consent cannot be expressed because of severe disability, assumptions should not be made that sexual pleasure is not required" (p. 153). In other words, the person being sexualized is merely a piece of flesh, whose consent and real feelings are irrelevant. Bindel quotes a few punters who carry a burden of guilt: "In Cambodia, I knocked back a lot of children, it makes it hard to sleep at night" (p. 158). But for most punters, there is no regret, no remorse, at being able to pay money which enables them to rape another human being. 
This leads Bindel to her sixth chapter on Human Rights and Wrongs. She addresses a profound paradox: "While women all over the world fight to end male supremacy, there are men and women in leftist and liberal politics who appear to consider defending the rights of men to challenge that assumption" (p. 160). Bindel deftly deconstructs the arguments of groups such as Amnesty International who argue for the removal of all legal constraints on the organization and practice of prostitution. She writes: "Human rights do not stretch to women in prostitution. Despite decades of feminism, "human" still means "man" (p. 166). All that groups like Amnesty can offer women is "the right to be abused." This seems to me to a very clear proposition, entirely consistent with the research evidence. And, as Bindel writes, while faux-feminists have the right to advocate a system of lack of control, they do not have the right to block services which address problems of boys, girls and women who are at risk of entering prostituted sex roles, nor the right to block services (or funding for such services) which help women exit.

Why, on libertarian grounds are services blocked or discouraged for "India's most marginalized girls and women who are sold into prostitution between the ages of 9 and 13, and who are poor, low-caste and extremely vulnerable" (p. 174)? Bindel quotes from a powerful speech by Ruchira Gupta in New York in 2015:

... prostitution is an outcome of inequality and not of choice. The punishment of pimps, johns and brothel-keepers is what prostituted women and their daughters want ... We need to invest in the 'last girl' who is trafficked because of her vulnerabilities. The 'last girl' is someone who is marked by multiple oppressions. She is the weakest of all human beings. She is weaker than the poor man, because she is female, she is weaker than the adult female because she is a teenager, she is weaker than the poor, female teenager because she is low-caste in India ... I pleaded for UN Women to punish those who buy and sell her vulnerabilities. I reminded them that the UN Declaration of Human Rights stood for protection of the weak and not the powerful (pp. 175-6).

This statement applies to all prostituted adolescents and women, everywhere. They come from the poorest groups of society, and often from the most stigmatized ethnic groups.

Chapter 7 addresses the issue of Aiding the Fight for Legislation: AIDS \& HIV. Bindel and other writers consider it bizarre that legalizing prostitution in a legal laissez-faire environment should have any effect on STIs (sexually transmitted infections), especially when customers can force women to have sex without a condom (or the man pulls off the condom and ejaculates in the women at the last moment). HIV is not principally an STI, but is transmitted through blood-to-blood transmission (e.g., shared needles, and through anal intercourse with tearing of skin). STIs (gonorrhea, syphilis, chlamydia, and other diseases) are diseases with primary sexual transmission, with many serious long-term health consequences, including carcinoma, miscarriage, and sterility. In Bangladesh, with its huge, unregulated brothel villages STI rates affect a quarter of prostituted girls and women, and rates are also high in married women whose husbands have used prostitutes (Bagley et al., 2017).

Bindel offers logical critiques of public health policy which claims that "liberalization" will result in lowered HIV rates. If numbers of prostituted women greatly increase under liberal regimes, any public health gains are lost. In a liberal regime 
the prostituted woman will do what her pimp-controller requires. If the woman becomes HIV positive, the pimp has a financial incentive to keep the woman working, as we found in our research with Nepalese women trafficked to India (Simkhada \& Bagley, 2008.)

In decriminalization regimes, Bindel concludes, there needs to be a network of support services which prevent entry, ensure the health of women unable to leave prostitution, and enable women to exit. She writes:

HIV prevention cannot possibly be effective until the structure of sexual equality is challenged as a core component of HIV prevention policy and programmes. We are not close to this yet. Over the years substantial funding has found its way to organisations and individuals involved in pimping, brothel keeping and even trafficking (p. 209).

In her eighth chapter on Fighting for Rights or Parasites? Bindel seeks to uncover some of the criminal elements allowed to flourish in the sex trade. She asks: "How have these people been allowed to hide in plain sight?" (p. 209). She gives detailed accounts from transcripts of public hearings to make her points, including an account of the notorious academic, John Davies who obtained many millions in grants to support the trafficking of prostituted women. Bindel continues her critique of biases in academic research in the next chapter. The false premise that a "free prostitute" is a reality prevails in many university departments of social science, and it has become difficult to publish papers, however, sound their methodology, which show the opposite. Bindel continues with a critique of The Queer Defence of the Sex Trade, in which gay pressure groups argue that boys expressing their sexuality in prostitution should be recognized and supported, even though these boys are minors, and are often being sold as part of "survival sex." The position of these writers, Bindel argues, amounts to a defense of child sexual abuse. She writes:

Of course child rape cannot be separated from the sex trade, just as trafficking cannot be. The sex trade will cease to function if its capacity to source desperate and vulnerable women and girls to be sold to men is frustrated (p. 297).

In her final two chapters, Bindel focuses on accounts of survivors. Systematic studies of prostituted women giving accounts of their lives offer the most powerful arguments against policies which tolerate or encourage the continued prostitution of vulnerable women and children. These are the only authentic voices in the debate about "the sex trade." The libertarians and exploiters of women ignore these voices. Neo-liberal ideologies have corrupted the debate, and produced a false picture of prostitution as freely chosen "work." Survivors who speak out are harassed and bullied by the faux-freedom lobby. But what freedom is there in "sex work"? In answer to this question Bindel offers a quotation from one of in her interviewees:

I got raped every week, every day - I was incontinent. I would do blow jobs in just the state I was in. They should see the state I was in and come and get me and rape me. I couldn't remember who I was. I didn't know who 
this guy was who raped me yesterday and who rape me again today (p. $305)^{2}$

Finally, Bindel concludes:

Those governments, policymakers, service providers and individuals who argue that the sex trade can never be abolished and therefore should be regulated and 'managed' are lacking in imagination. The same attitude is never applied to poverty in Africa, child sexual abuse, or cancer. The fight against the tobacco industry is perhaps a good analogy with the campaign to end the normalisation of pimping, brothel owning and sex buying ... (p. 335).

This excellent book can form a handbook for the next group of campaigners against legal systems which allow the trafficking, entrapment, and 'the slavery rape' of prostituted boys, girls, and women. What the book lacks (but others will supply) is a theoretical overview of why society allows this exploitation to continue, and how campaigns for change may be most effectively organized. Bindel's book contains enough material for a useful doctoral thesis in public policy, which will put her rich seams of knowledge and information into a theoretical framework.

Another recent book by a British feminist, Kat Banyard's Pimp State (2016), reviewed recently in this journal (Bagley, 2017), offers a message that is often similar to that of Julie Bindel. In enthusiastically reviewing Pimp State, I mentioned three areas in her arguments against 'the state as pimp' which could be strengthened: a lack of emphasis on child sexual abuse as a precursor for many of entering commercially sexually exploited roles; not enough emphasis on survivors who organise to help other women to exit; and lack of emphasis on programs in countries such as the USA in which the criminal justice system seeks not to stigmatise prostituted women, but to offer them constructive 'routes out'. Bindel covers all of these omissions or lack of emphases. In effect, Bindel is the underlaborer (in critical realist terms), the careful and logical researcher who offers intellectual and evidential support for other brilliant writers such as Banyard. When I go into battle on behalf of boys, girls, and women who are abused by the prostitution industry, I shall carry Bindel's book in my left hand, and Banyard's book in my right.

\section{ACKNOWLEDGMENTS}

Dignity thanks the following students for their time and expertise in editing this book review essay: Lily Lachapelle, major in psychology and gender and women's studies with a minor in Arabic; and Doriana Magliocchi, major in psychology with a minor in gender and women's studies, University of Rhode Island.

\footnotetext{
2 Fecal incontinence occurs when repeated anal rape destroys the capacity of the anal muscles. Use of heroin or morphine derivatives tends to check this incontinence (based on this reviewer's experience as a teenager trapped in the "survival sex" industry). Today (from our work with adolescents in Calgary) prostituted girls and women may resort to wearing "adult pampers" (designed for the incontinent elderly). Some punters enjoy raping girls and women who are wearing pampers. For the reviewer's personal account of being a juvenile sex worker, see "Robin - a bisexual identity" in Chapter 8 "Policies for gay and lesbian youth" in Bagley (1997).
} 


\section{AUTHOR BIOGRAPHY}

Christopher Adam Bagley is a Muslim-Quaker, and with Muslim colleagues is currently researching the sexual exploitation of girls and women in Bangladesh, building the case for an Islamic feminism. He held the Senator Patrick Burns Chair of Child Welfare at the University of Calgary, and also held chairs of social work and child welfare at universities in Britain and Hong Kong. He is currently Honorary Professor of Social Science at the Public Health Institute, Liverpool John Moores University, UK.

\section{RECOMMENDED CITATION}

Bagley, Christopher Adam. (2018). Prostitution and public policy: The Nordic model versus The Pimping of prostitution. Dignity: A Journal of Sexual Exploitation and Violence. Vol. 3, Issue 1, Article 3. https://doi.org/10.23860/dignity.2018.03.01.03.

\section{REFERENCES}

Alderson, P. (2013). Childhoods Real and Imagined: An Introduction to Critical Realism and Childhood Studies. Abingdon: Routledge.

Alderson, P. (2016). The Politics of Childhoods Real and Imagined: Practical Application of Critical Realism and Childhood Studies. Abingdon: Routledge.

Archer, M.A. (2012). The Reflexive Imperative in Late Modernity. Cambridge: Cambridge University Press.

Bagley, Christopher. (1997). Children, Sex and Social Policy: Humanistic Solutions for Problems of Child Sexual Abuse. Aldershot: Ashgate.

Bagley, Christopher. (2017). Book review: Pimp State: Sex, Money and Equality by Kat Banyard. Dignity: Journal of Sexual Exploitation and Violence, Vol. 2, Issue 2, Article 12. https://doi.org/10.23860/dignity.2017.02.02.06

Bagley, Christopher. (2018). Towards a realist criminology: review of What is to be Done About Crime and Punishment: Towards a 'Public Criminology' edited by Roger Matthews. Open Access Library Journal, in press.

Bagley, Christopher, Sawyerr, Alice. \& Abubaker, Mahmoud. (2016). Dialectical critical realism: grounded values and reflexivity in social science research. Advances in Applied Sociology, 6, 400-419. https://doi.org/10.20944/preprints201609.0052.v1

Bagley, Christopher, Khadri, Sadia, Shanaz, Afroze, Simkhada, Padam \& King, Kathleen. (2017). Commercialized sexual exploitation of children, adolescents and women: health and social structure in Bangladesh. Advances in Applied Sociology, 7, 137150. https://doi.org/10.4236/aasoci.2017.74008

Banyard, Kat. (2016). Pimp State: Sex, Money and Equality. London: Faber and Faber.

Bindel, Julie. (2016). The shocking tale of John Davies, pro-prostitution academic \& trafficking denier, recently jailed for fraud. Feminist Currents, June 10, 2016, online at www.feministcurrent.com. Retrieved October 13, 2017.

Farley, Melissa, Bindel, J. \& Golding, J. (2009). Men Who Buy Sex: Who They are and What They Want. London: Eaves; and San Francisco: Prostitution Research and Education (available online).

Johnson, H. \& Matthews, Roger. (2016). Addressing prostitution: the Nordic model and beyond. In R. Matthews (Ed.) What is to be Done About Crime and Punishment? Towards a 'Public Criminology' (pp 291-305). London: Palgrave-MacMillan.

Matthews, R. (2008). Prostitution, Politics and Policy. London: Routledge. 
Raymond, Janice. (2013). Not a Choice, Not a Job: Exploring the Myths about Prostitution and the Global Sex Trade. Washington, DC: Potomac Books.

Sawyerr, A. \& Bagley, Christopher. (2017). Equality and Ethnic Identities: Studies of SelfConcept, Child Abuse and Education in a Changing English Culture. Leiden: Brill - Sense Education Series.

Simkhada, P. and Bagley, Christopher. (2008). Excluded and exploited: the sexual trafficking of girls and women from Nepal to India. In C. Bagley and G. Verma (Eds.) Challenges for Social and Educational Inclusion: Studies from Britain and the Indian Sub-Continent (pp 219-264). Leiden: Brill - Sense Educational Series. 